\title{
Short communication: Increasing the teatcup removal settings of the last milking quarter did not reduce box time in a pasture-based automatic milking system
}

\author{
P. Silva Boloña, ${ }^{1,2 *}$ D. J. Reinemann, ${ }^{3}$ and J. Upton ${ }^{1}$ \\ ${ }^{1}$ Animal and Grassland Research and Innovation Centre, Teagasc Moorepark Fermoy, Co. Cork, Ireland P61C996 \\ ${ }^{2}$ Department of Dairy Science, University of Wisconsin-Madison, Madison 53706 \\ ${ }^{3}$ Biological Systems Engineering Department, University of Wisconsin-Madison, Madison 53706
}

\begin{abstract}
This research followed our previous experimental and simulation work on the effect of different teatcup removal settings based on the rolling average milk flowrate and on milking duration at the quarter and udder levels. The aims of this experiment were to (1) quantify the differences in quarter milking duration in a pasture-based automatic milking system and (2) test the effect of increasing the milk flowrate at which teatcups are removed on the last milking quarter on udder milking duration, box time, milk production rate, and somatic cell count (SCC). Milking duration is an important component of efficiency and profitability in conventional and automatic milking systems. Additionally, quarters within an udder have significantly different milk yields and milking durations. This study used data from April to May 2018 of a pasture-based automatic milking system to evaluate quarter milking duration differences between quarters of an udder. Subsequently, we experimentally evaluated the use of 2 percentage-based teatcup removal settings applied to the last milking quarter (i.e., the last quarter with a teatcup still attached) on milking duration, box time, milk production rate, and SCC. The teatcup removal settings were at 30 or $50 \%$ of the last quarter's rolling average milk flowrate, while the other quarters remained at the $30 \%$ level. The selection of the quarter that would receive the more aggressive teatcup removal setting was determined by identifying the last quarter with a teatcup attached in every milking. Sixty-nine cows were divided into 2 groups that each received 1 of the 2 treatments for a 1-wk period and then switched to the other treatment for a second week. For the months of April and May 2018, quarter milking duration was
\end{abstract}

Received March 3, 2020.

Accepted September 1, 2020.

*Corresponding author: pablo.silvabolona@teagasc.ie significantly different between the quarter with the longest and the second longest milking duration within an udder. The quarter with the longest milking duration was milked on average $49 \mathrm{~s}$ longer than the quarter with second longest milking duration. However, in $36 \%$ of the milkings, the quarter with the longest milking duration was different from that of the previous milking. In the experimental part of this study, we saw no differences in milking duration, box time, milk production rate, or SCC between the 30 and $50 \%$ teatcup removal setting applied to the last milking quarter. Further research on using a variation of this percentage-based setting to target the quarter with the average longest milking duration or using an absolute milk flowrate switchpoint or a maximum milking duration setting on the last quarter for reducing cow milking duration and box time is warranted.

Key words: teatcup removal setting, slowest quarter, milking duration, milking efficiency

\section{Short Communication}

The adoption of automatic milking systems (AMS) has made information about milk yield (MY), milking duration (MD), and milk flowrates at the quarter level readily available. This information shows that quarters within a typical udder are not equal in terms of MY and MD. For example, a study by Ipema and Hogewerf (2002) found differences in MY of $1 \mathrm{~kg}$ between the front and rear quarters, while Penry et al. (2018) found that rear quarters had on average $0.7 \mathrm{~kg}(25 \%)$ higher MY than front quarters. Additionally, Penry et al. (2018) performed a ranking of quarters according to their udder MY contribution and found that rear quarters were the highest or second highest MY contributor approximately $75 \%$ of the time. However, roughly $40 \%$ of the quarters changed rank within a 10-d window (Penry et al., 2018).

Milk yield is closely associated with the duration of milking (Edwards et al., 2014); therefore, there are 
significant intra-udder differences in MD of individual quarters. Tančin et al. (2006) reported differences in intra-udder average quarter milking duration $\left(\mathbf{M D}_{\mathbf{Q}}\right)$ of up to 43 s. Ipema and Hogewerf (2002) reported a significant 41-s higher MD for rear quarters compared with front quarters. Additionally, Ipema and Hogewerf (2008) showed a 16-s difference in MD between the 2 rear quarters, which were the quarters with the longest MD. A study on the effect of simulated teatcup removal settings on MD showed that the quarter with the longest milking duration had 48-s longer milkings than the average quarter (Silva Boloña et al., 2020).

Reducing MD by increasing the milk flowrate switchpoint (milk flowrate at which the teatcup is removed) at the udder and quarter level is a strategy that has been previously studied in conventional milking and AMS, respectively. A common concern is the negative effect that this can have on MY and SCC. However, Clarke et al. (2008) observed that increasing the milk flowrate switch-point from $300 \mathrm{~mL} / \mathrm{min}$ to $800 \mathrm{~mL} /$ min resulted in leaving $0.3 \mathrm{~L}$ of extra milk in the udders, but did not affect quarter SCC in either infected or uninfected quarters. Rasmussen (1993) reported a reduction in udder MD of $31 \mathrm{~s}$ when increasing the milk flowrate switch-point from $0.2 \mathrm{~kg} / \mathrm{min}$ to $0.4 \mathrm{~kg} /$ min in a conventional milking system, with no effect on MY or SCC, although a higher incidence of subclinical infections due to coagulase-negative staphylococci was seen for the $0.4 \mathrm{~kg} / \mathrm{min}$ group. In high-yielding cows, Stewart et al. (2002) found a reduction of $15 \mathrm{~s}$ in udder MD by increasing the milk flowrate switch-point from $0.73 \mathrm{~kg} / \mathrm{min}$ to $0.82 \mathrm{~kg} / \mathrm{min}$ with no negative effect on MY. Furthermore, in a pasture-based conventional milking system, Edwards et al. (2013) found a significant reduction of $78 \mathrm{~s}$ when increasing the milk flowrate switch-point from $0.2 \mathrm{~kg} / \mathrm{min}$ to $0.8 \mathrm{~kg} / \mathrm{min}$ at the udder level without affecting MY or SCC.

Increasing the milk flowrate switch-point using an AMS was studied by Silva Boloña et al. (2019), where we evaluated a percentage-based milk flowrate switchpoint and observed that udder MD was reduced by $9 \mathrm{~s}$ when removing the teatcups when quarter milk flowrate was below $30 \%$ of the 30 -s rolling average milk flowrate of that quarter compared with $20 \%$. There were no differences in udder MD when using a milk flowrate switch-point of $50 \%$ of the quarter's 30-s rolling average milk flowrate compared with $30 \%$. Additionally, the 20,30 , and $50 \%$ of average milk flowrate switch-points were not different in milk production rate (MPR) or SCC. These findings agreed with those of Upton et al. (2019) in a trial that evaluated 2 system vacuum treatments and a similar $30 \%$ and $50 \%$ of average milk flowrate switch-point. Furthermore, Krawczel et al. (2017) used an absolute quarter milk flowrate switch- point in an AMS (0.06 kg/min vs. $0.48 \mathrm{~kg} / \mathrm{min})$ and found a significant 54-s reduction in udder MD with no effect on MY or SCC. In the previous studies that used a switch-point of $50 \%$ of the quarter's rolling average milk flowrate, an additional criteria was applied by which teatcups were not removed if the milk flowrate of the quarter was above $0.5 \mathrm{~kg} / \mathrm{min}$; this affected $13 \%$ of milkings as reported by Upton et al. (2019) and $25 \%$ of the milkings as reported by Silva Boloña et al. (2019), limiting the effect of this milk flowrate switch-point. Conversely, results from a simulated teatcup removal setting study showed that quarter MD could be reduced by $24 \mathrm{~s}$ by using a quarter milk flowrate switch-point of $50 \%$ of that quarter's 30 -s rolling average milk flowrate compared with $30 \%$ of the quarter's rolling average milk flowrate (Silva Boloña et al., 2020). Additionally, it was estimated that by increasing the milk flowrate switch-point on the quarter with the longest milking duration from 30 to $50 \%$ of the quarter's 30 -s rolling average milk flowrate, MD of that quarter could be reduced by $30 \mathrm{~s}$ (Silva Boloña et al., 2020). However, in the study of Silva Boloña et al. (2020), the differences on MD were at the quarter level, which may not necessarily result in a reduction in udder MD or box time (BT), as opposed to the udder level for the Upton et al. (2019) and Silva Boloña et al. (2019) trials.

Therefore, due to the potentially large differences in MD between quarters of a cow and the possibility of significantly reducing MD, the objectives of this study were as follows: (1) to quantify the differences in quarter MD with information from a pasture-based AMS and (2) to test the effect of increasing the milk flowrate switch-point of the last milking quarter on cow $\mathrm{MD}$, BT, MPR, and SCC.

This research was carried out at the Teagasc Moorepark research facility (Cork, Ireland). The farm operated a spring calving, grass-based AMS. The farm was divided into 4 areas with 1 grazing allocation made available daily in each area. Cows gained access to each allocation through sorting gates when they visited the milking shed. Access to each allocation was available for approximately $6 \mathrm{~h} / \mathrm{d}$, one after the other. When cows start depleting the grass allowance in an allocation, they start to leave it to gain access to a new allocation. In the robot, $0.5 \mathrm{~kg}$ of concentrate feed per day was provided. Eighty-five cows were milked using a single Astronaut A4 robotic milking system (Lely, the Netherlands) with an average milking frequency of 1.6 milkings per day. The system vacuum level was set to $43 \mathrm{kPa}$, the pulsator ratio was $65: 35$, and a pulsation rate of 60 per minute was used.

Information for udder MD (s), $\mathrm{MD}_{\mathrm{Q}}(\mathrm{s}), \mathrm{BT}(\mathrm{s}), \mathrm{MY}$ $(\mathrm{kg})$, udder average milk flowrate (AMF, $\mathrm{kg} / \mathrm{min}$ ), and udder peak milk flowrate $(\mathbf{P M F}, \mathrm{kg} / \mathrm{min})$ were re- 
trieved from the AMS farm management software (Lely T4C). Udder MPR $(\mathrm{kg} / \mathrm{h})$ was calculated by dividing MY for each milking by the milking interval. Two distinct concepts will be used throughout the manuscript that are related but not the same. They are defined as follows: (1) slowest quarter (SQ), the quarter with the longest teatcup on time (therefore quarter with the longest MD); (2) last milking quarter (LQ), the last quarter with the teatcup still attached at a given milking (i.e., while 3 quarters have had the teatcup removed, the remaining quarter is the last quarter). For the evaluation of objective $1, \mathrm{SQ}$ was the variable used because the AMS software did not provide information on which quarter was the LQ, and the use of SQ represented the best available estimation of the LQ. Conversely, LQ was used for the experiment of objective 2 because it was not possible to select a teatcup removal setting for the SQ in this AMS.

For the analysis of quarter MD differences (objective 1), a data set that consisted of more than 9,000 milkings in the AMS from the months of April and May 2018 were used. The SQ for each milking of each individual cow was identified using the SAS Rank procedure (SAS 9.4 statements, SAS Institute Inc., Cary, $\mathrm{NC}$ ) to rank quarters by their MD in each milking. The position of the SQ, the frequency at which each quarter position was the SQ, and MD differences between the SQ and second SQ were computed on a per milking and per cow basis. Statistical analysis of the difference in MD between the $2 \mathrm{SQ}$ was performed using a Wilcoxon signed rank test for nonparametric dependent samples due to the nonnormal distribution of these data. Milkings with long milking intervals (time since the cow's last milking) of over $24 \mathrm{~h}$, failed milkings, or milkings where 1 or more quarters did not produce any milk were removed from the data set.

To test the effect of increasing the milk flowrate switch-point of the LQ on udder MD (objective 2), cows were admitted into the study group provided they did not present with a clinical case of mastitis during the current milking season and had an udder level SCC of less than 200,000 cells/mL at a milk recoding test carried out 1 wk before the experimental treatments started. A total of 69 cows met the enrolment criteria for the experiment, which consisted of 62 Holstein Friesians, 2 Jerseys, and 5 Holstein Jersey crossbreds. Their average DIM at the start of the experiment was $82 \mathrm{~d}$ $(\mathrm{SD}=25)$. Parity ranged from 1 to 8 with a mean of $3.1(\mathrm{SD}=1.9)$. Cows were blocked based on parity $(1$, $>1$ ), breed (Holstein Freiesian, Jersey, Holstein Jersey), and PMF at the udder level $(<3.5, \geq 3.5 \mathrm{~kg} / \mathrm{min})$ using milking data from 1 mo before the start of the trial. After blocking, cows in each block were randomly assigned to 1 of 2 treatment groups.
Teatcup removal settings in this AMS were based on a percentage of the milk flowrate; the mechanism for its calculation is described in Silva Boloña et al. (2019). For the purposes of this experiment, milk flowrate switch-point for the LQ was applied independently of the other 3 quarters. This setting was modified in the AMS farm management software (Lely T4C) for each cow, and it was not possible to preselect which quarter received the different milk flowrate switchpoint. The control treatment removed all individual teatcups when the quarter milk flowrate fell below $30 \%$ of the quarter 30-s rolling AMF (LQ30). The second treatment removed the teatcup of the LQ when quarter milk flowrate dropped below $50 \%$ of the 30 -s rolling AMF (LQ50), while the other 3 quarters were removed when quarter milk flowrate fell below $30 \%$ of the rolling AMF. Identification of the LQ was done at every milking by identification of the last remaining quarter with a teatcup still attached. If the LQ had a milk flowrate below $50 \%$ of the rolling average at the time that the third quarter's teatcup was detached, the teatcup removal sequence for the LQ was initiated. There was a $2 \mathrm{~kg} / \mathrm{min}$ limit that prevented teatcup removal on the LQ if the switch-point was reached, but the quarter flowrate was above this limit. Both settings had a 3-s delay, meaning that teatcups were removed $3 \mathrm{~s}$ after reaching the milk flowrate switch-point. The AMS did not provide information of the milk flowrate at which each teatcup was removed; therefore, an estimation was calculated by multiplying the AMF for the whole milking of the SQ by the treatment milk flowrate switchpoint (e.g., SQ AMF $\times 0.3$ for the LQ30 treatment). Before the start of the experiment, cows were normally milked using the control (LQ30) setting. The predicted SQ of the 2 rear quarters was attached first followed by the other rear quarter, and then the predicted SQ of the front quarters followed by the remaining front quarter. However, attachment order can vary depending on machine (e.g., dirty lens) or cow (e.g., kicking, stepping behavior) factors.

Each group of cows was randomly assigned 1 of the 2 treatments for $1 \mathrm{wk}$ and then switched to the other treatment the following week in a crossover design between June 6 and 20, 2018. The week of the experiment that each cow was assigned each treatment was identified and included in the analysis model because, with the pasture-based nature of this herd, grass growth and weather can have a large effect on milking frequency and MY. The last $2 \mathrm{~d}$ of each treatment period were used for milk sampling to obtain individual cow SCC data. Milk samples from each cow were collected using the Shuttle (Lely, The Netherlands), and SCC was measured using a Fossomatic machine (Foss, Hillerød, Denmark). Milk samples were treated in the Shuttle us- 
ing broad spectrum microtabs (Advanced Instruments Inc., Norwood, MA) in each milk sampling bottle to preserve the sample until it was transported to the milk testing laboratory. Data collected at every milking by the AMS farm management software (Lely T4C) were combined with the milk testing laboratory SCC results. Using the AMS automatic sampler caused an increase in BT; therefore, only the first $5 \mathrm{~d}$ of each treatment period were used for the analysis of milking performance outcome variables. Somatic cell count was $\log _{10}$ transformed due to the highly skewed nature of these data. The MD and BT were analyzed both with the raw values and $\log _{10}$ transformed due to the distribution characteristics of these variables.

The effect of milk flowrate switch-point on the following variables was assessed: $\mathrm{BT}, \mathrm{MD}, \log _{10} \mathrm{MD}$, $\log _{10} \mathrm{BT}, \mathrm{AMF}, \mathrm{PMF}, \mathrm{MPR}$, and $\log _{10} \mathrm{SCC}$. Milkings with milking intervals of over $24 \mathrm{~h}$, failed milkings, or milkings where 1 or more quarters did not produce any milk were removed from the analysis. A backward elimination process was followed to reduce the model to include only significant predictive variables. The mixed procedure (Proc Mixed, SAS) was used. Week $(1,2)$, treatment (LQ30, LQ50), block (1 to 8), group $(1,2)$, and cow were declared as class variables. Week, treatment, lactation number, and MY were classified as fixed effects. Cow nested in group, block, group, and block $\times$ group were declared as random variables. To account for autocorrelation of repeated measures on the same experimental unit (cow), we used an autoregressive covariance structure [AR(1) in SAS].

The following model statement shows the fixed effects used:

$$
\mathrm{y}=\mathrm{MY}+\text { week }+ \text { treatment, }
$$

where y represented the following dependent variables: MD (s), the time from first teatcup attachment to last teatcup removal; BT (s), the time that the cow was present in the AMS; $\log _{10} \mathrm{MD} ; \log _{10} \mathrm{BT} ; \mathrm{AMF}(\mathrm{kg} / \mathrm{min})$, udder level MY/MD; and PMF ( $\mathrm{kg} / \mathrm{min})$, the maximum 30-s rolling average. The model used to examine effects on SCC was as follows:

$$
\begin{aligned}
\log _{10} \mathrm{SCC}= & \mathrm{MY}+\text { lactation }+ \text { week } \\
& + \text { treatment. }
\end{aligned}
$$

The model used to examine effects on MPR was as follows:

$$
\mathrm{MPR}=\text { week }+ \text { treatment }
$$

where MPR is the udder MY divided by milking interval.

Table 1 shows descriptive statistics for this herd during the months of April and May 2018 before the start of the experimental period. We observed that $\mathrm{MD}_{\mathrm{Q}}$ of the $\mathrm{SQ}$ was $49 \mathrm{~s}$ longer $(\mathrm{SD}=26, P<0.0001$ ) on average than the second $\mathrm{SQ}$ of the same udder for the months of April and May 2018. The SQ had an average $\mathrm{MD}_{\mathrm{Q}}$ of $400 \mathrm{~s}(\mathrm{SD}=137)$, while the second $\mathrm{SQ} \mathrm{MD}_{\mathrm{Q}}$ was $351 \mathrm{~s}(\mathrm{SD}=124)$. In $83 \%$ of the milkings, rear quarters were the SQ. The SQ had an average of 0.6 $\mathrm{kg}(\mathrm{SD}=0.7)$ higher MY per milking compared with the second SQ. The SQ was also the highest yielding quarter in $46 \%$ of the milkings, and was the second highest in $26 \%$ of the milkings. In $64 \%$ of the milkings, the SQ was the same quarter as in the previous milking; therefore, SQ for each cow changed $36 \%$ of the time from the previous milking session. The percentage of an incomplete milking in the previous milking was $7 \%$ in quarters where the $\mathrm{SQ}$ was different from the $\mathrm{SQ}$ of the previous milking. When the $\mathrm{SQ}$ was the same as in the previous milking, the percentage of an incomplete milking in the previous milking was $1 \%$.

When increasing the milk flowrate switch-point (from LQ30 to LQ50) of the LQ, we saw no effect of the treatment on MD, BT, MPR, AMF, or PMF (Table 2 ). The difference between the LQ30 and LQ50 treat-

Table 1. Summary of several herd and milking variables before the experimental period

\begin{tabular}{llccc}
\hline Variable & \multicolumn{1}{c}{ Mean } & SD & Minimum & Maximum \\
\hline DIM & 82.4 & 24.8 & 24 & 121 \\
Milking interval $^{1}(\mathrm{~h})$ & $15.2(1.6 \times / \mathrm{d})$ & 1.9 & 11.8 & 18.9 \\
Box time $^{2}(\mathrm{~s})$ & 526 & 148 & 316 & 941 \\
Milking duration (s) $_{\text {Milk yield/milking (kg) }}^{439}$ & 148 & 231 & 862 \\
Milk yield/day (kg) & 15.5 & 2.9 & 6.5 & 20.0 \\
Connect time $^{3}(\mathrm{~s})$ & 24.4 & 6.0 & 9.2 & 36.3 \\
\hline
\end{tabular}

${ }^{1}$ Milking interval $=$ time in hours elapsed between milkings. Value in parentheses represents milking frequency (average number of milkings per day).

${ }^{2}$ Box time $=$ time in seconds that the cow spends inside the robot.

${ }^{3}$ Connect time $=$ time in seconds that it takes the robot to attach all teatcups. 
Table 2. Effect of 2 percentage-based milk flowrate switch-points applied to the last milking quarter on several variables related to milking efficiency and SCC

\begin{tabular}{lcccc}
\hline & \multicolumn{4}{c}{ Treatment } \\
\cline { 2 - 5 } Item & LQ30 & LQ50 & SEM & $P$-value \\
\hline Average udder milk flowrate $(\mathrm{kg} / \mathrm{min})$ & 2.4 & 2.4 & 0.03 & 0.6 \\
Peak udder milk flowrate $(\mathrm{kg} / \mathrm{min})$ & 3.6 & 3.6 & 0.1 & 0.8 \\
Milk production rate $(\mathrm{kg} / \mathrm{h})$ & 0.92 & 0.93 & 0.02 & 0.3 \\
Box time (s) & 479 & 473 & 9.8 & 0.2 \\
Milking duration (s) & 402 & 399 & 9.6 & 0.4 \\
Log $_{10} \mathrm{SCC}^{3}$ & 4.67 & 4.66 & 0.04 & 0.8 \\
\end{tabular}

${ }^{1}$ LQ30 = teatcup removal of the last quarter at 30\% of the quarter average flowrate.

${ }^{2} \mathrm{LQ} 50=$ teatcup removal of the last quarter at $50 \%$ of the quarter average flowrate.

${ }^{3}$ In parentheses is the back transformed $\log _{10} \mathrm{SCC}$.

ments on the log-transformed MD and BT (0.004 and 0.006 respectively) was not statistically significant $(P=$ 0.27 and $P=0.06$, respectively). Based on sample size calculations according to Snedecor and Cochran (1989), our detectable difference for MD was $55 \mathrm{~s}$; therefore, this study lacked power to detect the numeric difference observed between the LQ30 and LQ50 treatments (3-s difference, see Table 2), which is not a relevant difference in practical terms. When the sample size calculation was performed using the $\log _{10}$ transformed data, the detectable difference for MD was 0.04 in the $\log _{10}$ scale; therefore, this study also lacked power to detect the 0.004 and 0.006 differences found in $\log _{10^{-}}$ transformed $\mathrm{MD}$ and $\mathrm{BT}$. Both $\mathrm{MD}$ and $\mathrm{BT}$ were positively associated with increased MY $(P<0.0001)$. Each kilogram increase in MY increased MD and BT by 29 s. Somatic cell count was not significantly affected by the teatcup removal treatments or associated with lactation number.

The 49-s difference in $\mathrm{MD}_{\mathrm{Q}}$ between the $\mathrm{SQ}$ and second SQ observed in this study was similar to that reported by Tančin et al. (2006), who showed an average 43-s MD difference between the quarter with the shortest and longest MD, but a much smaller 3-s difference in MD between the quarters with the average longest and second longest MD. Our results were larger than those of Ipema and Hogewerf (2008), who reported differences in MD of $16 \mathrm{~s}$ between the 2 rear quarters, with the 2 rear quarters also identified as having the longest MD.

Milk yield influences MD, as previously cited by Edwards et al. (2014); however, it is not the sole factor that can drive MD. This is supported by our results where the SQ was the highest or the second highest yielding quarter in $70 \%$ of the milkings. Additionally, anatomical characteristics of the quarters affect milk flowrates, which also influence MD. Weiss et al. (2004) found a significant negative correlation between quarter teat length, which was greater in front quarters, and
$\mathrm{MD}$; therefore, quarters with greater teat lengths would have shorter MD. Moreover, Weiss et al. (2004) found a significant negative correlation between quarter teat canal length and peak flowrate and between peak flowrate and $\mathrm{MD}_{\mathrm{Q}}$.

The average milking interval in this study was $15 \mathrm{~h}$, which is longer than most conventional milking systems and other AMS systems (Lyons and Kerrisk, 2017). It is possible that the differences observed in $\mathrm{MD}_{\mathrm{Q}}$ could be due to these very long milking intervals. Profiles of milk accumulation show that milking interval reduced the rate of milk secretion after $12 \mathrm{~h}$ since the last milking (Knight et al., 1994). Additionally, glands with larger cisterns (which is the case for rear quarters) could be more tolerant to this milk-suppression effect (Ayadi et al., 2003). However, MPR is lower in front quarters, and thus the time that it takes to fill both rear and front quarters might be similar. This is supported by Ayadi et al. (2003), who found that both cisternal and alveolar fill decreased roughly after $16 \mathrm{~h}$ in both front and rear quarters. Moreover, there were no differences in cisternal area between the left and right quarters, which could indicate that the effect of milking interval on milk secretion is similar for both sides of the udder (Ayadi et al., 2003). Therefore, it is unlikely that milking interval affected the quarters of an udder differently, and thus unlikely that it played a major role in the large differences found in $\mathrm{MD}_{\mathrm{Q}}$ between the $\mathrm{SQ}$ and the second SQ.

The SQ in our study was not always the same quarter for a cow across all milkings; therefore, classifying MD based on a fixed quarter position would underestimate differences in $\mathrm{MD}_{\mathrm{Q}}$. This is particularly true in our study, where the SQ changed from milking to milking $36 \%$ of the time, similar to the results presented by Penry et al. (2018) for quarter MY contribution. A previous incomplete milking in one quarter could explain changes in SQ position by this quarter having higher MY at the time of the next milking. Additionally, some 
AMS allow short milking intervals if there was an incomplete milking in the previous milking, which was the case for the AMS used in this study. These situations can create milking interval differences between quarters from milking to milking, resulting in differences in quarter MY and a change in the SQ. Bach and Busto (2005) mentioned that milking interval increased from $12 \mathrm{~h}$ to $21 \mathrm{~h}$ in incompletely milked quarters. Moreover, they commented that MY following an incomplete milking was numerically greater in incompletely milked quarters, but it was $26 \%$ lower when corrected by milking interval (Bach and Busto, 2005). Our results only partially support this hypothesis. While the percentage of incomplete milkings was greater in cows that changed the SQ from one milking to the next compared with the ones that did not, it was only a very small proportion of these milkings $(7 \%)$. Bach and Busto (2005) reported that following an incomplete milking, the quarter recovered the original level of milk production within 7 milkings, which could support the idea that the changes in the SQ extend beyond the milking where the incomplete milking occurred. Other factors such as how teatcups are positioned on teats, teatcup slip, or crawl could influence this change as well. These results provide grounds for further research on factors that influence MD at the quarter level.

This study showed that there was no effect of the early teatcup removal of the LQ strategy on MD. Individual cow MD is an important driver of efficiency in AMS, and Silva Boloña et al. (2020) suggested that the quarter with the longest MD (SQ) was a major determinant of cow MD for switch-points of $0.6 \mathrm{~kg} / \mathrm{min}$ or lower. To our knowledge, there have been no studies conducted to test different milk flowrate switch-points as a criterion for the end of milking applied to the LQ. Cows in this trial were in peak lactation, and it is possible that results could be different in later stages of the lactation as milk production decreases. However, Penry et al. (2018) found differences in quarter MY contribution to total MY in all stages of lactation; therefore, a similar result could be expected due to its relationship with MD.

The AMS used in this study identified the LQ at each milking (the last quarter that is left with the teatcup attached), and it is possible that LQ would be different between milkings depending on the attachment order and other factors. If the SQ (quarter with the longest $\mathrm{MD}$ ) is attached first, that quarter might not be the LQ (i.e., last quarter to finish milking). This is supported by Penry et al. (2018), who reported that attaching the SQ first is a more efficient way of harvesting milk per minute in the AMS compared with attaching the fastest quarter first. Usually, the AMS used in this study attempted to attach the SQ first and always attempted to attach the rear quarters before front quarters. Unfortunately, the AMS software does not provide information on which quarter was the LQ in each milking, so we were not able to identify for each milking which quarter received which switch-point treatment. However, the time that it took to connect all teatcups (connect time) in this experiment was $45 \mathrm{~s}$ on average (see Table 1), or about $11 \mathrm{~s}$ per quarter. If the SQ was attached first, this would not have compensated for the considerably longer $\mathrm{MD}_{\mathrm{Q}}$ difference between the $\mathrm{SQ}$ and second $\mathrm{SQ}$ (49-s difference). Therefore, it does not appear that attachment order might have played a role in the lack of effect observed by increasing the switch-point.

When analyzing the estimations for milk flowrate at teatcup removal, there was a $0.14 \mathrm{~kg} / \mathrm{min}$ difference in teatcup removal flowrate between the LQ30 and LQ50 treatments $(0.21 \mathrm{~kg} / \mathrm{min}$ vs. $0.35 \mathrm{~kg} / \mathrm{min}$, respectively), which is similar to the estimated difference of $0.11 \mathrm{~kg} /$ min found by Silva Boloña et al. (2020). The differences found in the estimated milk flowrate at teatcup removal might not have been sufficient to affect $M D$, considering that these differences were affecting only 1 quarter. However, Silva Boloña et al. (2020) reported a 30-s reduction in $\mathrm{MD}_{\mathrm{Q}}$ by increasing the milk flowrate switch-point from 30 to $50 \%$ of the quarter rolling AMF for the SQ, but this reduction was in quarter MD rather than udder MD, as reported in the present study. The small differences in milk flowrate at teatcup removal between both treatments appeared to be the main factor affecting the lack of differences on MD, in agreement with data reported by Upton et al. (2019) and Silva Boloña et al. (2019). The 50\% milk flowrate switch-point is the maximum that can be set by the user in this AMS, and it is possible that a higher switch-point might produce a significant effect on MD. This is also supported by Silva Boloña et al. (2020), who reported a $0.08-\mathrm{kg}$ difference in strip milk by applying a simulated milk flowrate switch-point of $50 \%$ of the quarter's rolling average compared with $30 \%$. The time that it would take to harvest this $0.08-\mathrm{kg}$ strip milk differential would be very short, and consequently not result in any practical reduction in MD.

Using a percentage of the AMF as the criterion for quarter end of milking creates large variability in milk flowrate at teatcup removal because low milk flowrate quarters might have a calculated milk flowrate switchpoint that is much lower compared with high milk flowrate quarters. This is evident in the distribution of the teatcup removal milk flowrate (from $0.1 \mathrm{~kg} / \mathrm{min}$ to $>0.8 \mathrm{~kg} / \mathrm{min}$ ) for the treatment where the teatcup was removed at $50 \%$ of the quarter's AMF in the study by Silva Boloña et al. (2019). Furthermore, it is possible that the time elapsed between the teatcup removal of the LQ and the second LQ was very short; therefore, 
increasing the switch-point of the LQ would not result in a reduction of cow MD and $\mathrm{BT}$. However, considering the large differences in quarter MD, this seemed less likely. Moreover, if at the time that the third teatcup was removed, the last quarter's milk flowrate was between 30 and $50 \%$ of its rolling AMF, then the teatcup would have been removed shortly after the third quarter. Having information on which quarter received the increased switch-point and the milk flowrate curves for all the quarters would have been a very valuable tool to assess the effect of this milk flowrate switch-point setting and should be considered for future research.

In summary, applying a higher milk flowrate switchpoint, defined as a percentage of the rolling AMF on the LQ, did not produce a significant reduction in MD or BT, despite the significant differences in MD between the SQ and second SQ. A strategy that uses an absolute milk flowrate switch-point on the SQ and a strategy that establishes a maximum cow $\mathrm{MD}$ as shown by Jago et al. (2010) have shown greater capacity for reduction of MD. Additionally, a strategy that establishes a maximum MD of the SQ may be more effective at reducing cow MD than a percentage-based milk flowrate switch-point. Therefore, further research exploring these strategies would be interesting.

\section{ACKNOWLEDGMENTS}

The authors gratefully acknowledge funding from Teagasc (Teagasc Moorepark, Fermoy, Co. Cork, Ireland) and from the Teagasc Walsh Fellowship Programme (Carlow, Ireland). We also acknowledge the support of the University of Wisconsin-Madison (Madison, WI), and Lely (Maassluis, the Netherlands). We acknowledge the technical assistance of Caroline O'Sullivan at the Dairygold research farm at Teagasc Moorepark (Cork, Ireland). We acknowledge Peter Crump at the Statistical Consulting Group in the College of Agricultural and Life Sciences (University of Wisconsin-Madison) for statistical advice. The authors confirm that there are no conflicts of interest.

\section{REFERENCES}

Ayadi, M., G. Caja, X. Such, and C. H. Knight. 2003. Use of ultrasonography to estimate cistern size and milk storage at different milking intervals in the udder of dairy cows. J. Dairy Res. 70:1-7. https://doi.org/10.1017/S0022029902005873.

Bach, A., and I. Busto. 2005. Effects on milk yield of milking interval regularity and teat cup attachment failures with robotic milking systems. J. Dairy Res. 72:101-106. https://doi.org/10.1017/ S0022029904000585.

Clarke, T., E. M. Cuthbertson, R. K. Greenall, M. C. Hannah, and D. Shoesmith. 2008. Incomplete milking has no detectable effect on somatic cell count but increased cell count appears to increase strip yield. Aust. J. Exp. Agric. 48:1161-1167. https://doi.org/10 .1071/EA07259.

Edwards, J. P., J. G. Jago, and N. Lopez-Villalobos. 2013. Milking efficiency for grazing dairy cows can be improved by increasing automatic cluster remover thresholds without applying premilking stimulation. J. Dairy Sci. 96:3766-3773. https://doi.org/10.3168/ jds.2012-6394.

Edwards, J. P., J. G. Jago, and N. Lopez-Villalobos. 2014. Analysis of milking characteristics in New Zealand dairy cows. J. Dairy Sci. 97:259-269. https://doi.org/10.3168/jds.2013-7051.

Ipema, A. H., and P. H. Hogewerf. 2002. Detachment criteria and milking duration. Pages 33-44 in Proc. First North Am. Conf., Robotic milking, Toronto, Canada. Wageningen Pers., Wageningen, the Netherlands.

Ipema, A. H., and P. H. Hogewerf. 2008. Quarter-controlled milking in dairy cows. Comput. Electron. Agric. 62:59-66. https://doi.org/10 .1016/j.compag.2007.09.007.

Jago, J. G., J. L. Burke, and J. H. Williamson. 2010. Effect of automatic cluster remover settings on production, udder health, and milking duration. J. Dairy Sci. 93:2541-2549. https://doi.org/10 $.3168 /$ jds.2009-2949.

Knight, C. H., D. Hirst, and R. J. Dewhurst. 1994. Milk accumulation and distribution in the bovine udder during the interval between milkings. J. Dairy Res. 61:167-177. https://doi.org/10 $.1017 /$ S0022029900028181.

Krawczel, P., S. Ferneborg, L. Wiking, T. K. Dalsgaard, S. Gregersen, R. Black, T. Larsen, S. Agenäs, K. Svennersten-Sjaunja, and E. Ternman. 2017. Milking time and risk of over-milking can be decreased with early teat cup removal based on udder quarter milk flow without loss in milk yield. J. Dairy Sci. 100:6640-6647. https: //doi.org/10.3168/jds.2016-12312.

Lyons, N. A., and K. L. Kerrisk. 2017. Current and potential system performance on commercial automatic milking farms. Anim. Prod. Sci. 57:1550-1556. https://doi.org/10.1071/AN16513.

Penry, J. F., P. M. Crump, L. L. Hernandez, and D. J. Reinemann. 2018. Association of quarter milking measurements and cow-level factors in an automatic milking system. J. Dairy Sci. 101:75517562. https://doi.org/10.3168/jds.2017-14153.

Rasmussen, M. D. 1993. Influence of switch level of automatic cluster removers on milking performance and udder health. J. Dairy Res. 60:287-297. https://doi.org/10.1017/S0022029900027631.

Silva Boloña, P., D. J. Reinemann, and J. Upton. 2019. Effect of teatcup removal settings on milking efficiency and milk quality in a pasture-based automatic milking system. J. Dairy Sci. 102:84238430. https://doi.org/10.3168/jds.2018-15839.

Silva Boloña, P., J. Upton, and D. J. Reinemann . 2020. Effect of simulated quarter and udder teatcup removal settings on strip milk and milking duration in dairy cows. J. Dairy Sci. 103:4446-4454. https: //doi.org/10.3168/jds.2019-17266.

Snedecor, G. W., and W. G. Cochran. 1989. Statistical methods. 8th ed. Iowa State Univ. Press, Ames, Iowa.

Stewart, S., S. Godden, P. Rapnicki, D. Reid, A. Johnson, and S. Eicker. 2002. Effects of automatic cluster remover settings on average milking duration, milk flow, and milk yield. J. Dairy Sci. 85:818-823. https://doi.org/10.3168/jds.S0022-0302(02)74141-6.

Tančin, V., A. H. Ipema, P. H. Hogewerf, and J. Mačuhová. 2006. Sources of variation in milk flow characteristics at udder and quarter levels. J. Dairy Sci. 89:978-988. https://doi.org/10.3168/jds .S0022-0302(06)72163-4.

Upton, J., P. Silva Bolona, and D. J. Reinemann. 2019. Short communication: Effects of changing teatcup removal and vacuum settings on milking efficiency of an automatic milking system. J. Dairy Sci. 102:10500-10505. https://doi.org/10.3168/jds.2018-16035.

Weiss, D., M. Weinfurtner, and R. M. Bruckmaier. 2004. Teat anatomy and its relationship with quarter and udder milk flow characteristics in dairy cows. J. Dairy Sci. 87:3280-3289. https://doi.org/ 10.3168/jds.S0022-0302(04)73464-5. 